\title{
[Dissolution Influences on Gypsum Rock under Short and Long-Term Loading: Implications for Dams]
}

\author{
[Nihad B. Salih ${ }^{1}$, Philip E.F. Collins ${ }^{2}$, Stephen Kershaw ${ }^{3}$ ] \\ $\left[{ }^{1}\right.$ University of Sulaimani, Iraq, ${ }^{2}$ and ${ }^{3}$ Brunel University, London, UK]
}

Dissolution of soluble substrates such as gypsum presents a major hazard to dams in many parts of the world. This research simulates hypothesised conditions beneath the Mosul Dam, northwest Iraq, where collapse of a karstic system associated with continuous fresh water supply from its reservoir is a recognised problem. Gypsum rocks from northern Iraq and similar rocks from Bantycock gypsum mine, UK, were analysed for short-term mechanical response following immersion ( 5 to 50 weeks) and long-term loading during immersion (maximum 50 weeks). New experimental devices were developed from a conventional oedometer. Cylinder samples provided a proxy for massive gypsum strata. Samples were permanently submerged at atmospheric water pressure, with groundwater recharge, flow and dissolution simulated by regular changes of water. Stress on each sample was progressively increased to a maximum of $2688 \mathrm{kPa}$. Small increases in strain were recorded by the end of each test but no failures occurred within 60 days. However, notable failure due to atmospheric water pressure and axial stress occurred over long time periods. Visible physical changes included a decrease in sample mass and volume. Similar change was recorded in ultrasonic velocities. These indicate that gypsum collapse risk beneath dams requires prolonged exposure to dissolution. The modified device performed well and was robust, and demonstrates that such a modification can provide a simple low cost system for conducting laboratory creep tests on weak rocks.

Keywords: Gypsum Rock, Dissolution, Short-Term Loading, Long-Term Loading, Dams.

\section{[1 Introduction]}

Gypsum rock underly more than 20 percent of the earth surface [11] with seven million $\mathrm{km}^{2}$ underlain by highly soluble gypsum $\left(\mathrm{CaSO}_{4} \cdot 2 \mathrm{H}_{2} \mathrm{O}\right)$ bearing rocks in a large number of countries [5]. Its solubility in pure water is $2.531 \mathrm{~g} / 1$ at $20^{\circ} \mathrm{C}$, around 140 times lower than halite and 4 times larger than $\mathrm{CaCO}_{3}[12]$. 
Gypsum rock is common in Iraq, mainly in the Mid-Miocene Fatha (Lower Fars) Formation [10] and is associated with significant geotechnical problems. This is particularly the case in sites with high hydraulic gradients such as near dams [15] e.g. the Mosul Dam, which is underlain by thick gypsum beds which are severely affected by dissolution and karstification, including general subsidence and sinkholes.

While cavity formation due to dissolution is known, mechanical change leading to creep and brittle failure has received little attention. This is significant as the formation of cavities will transfer load to surrounding, potentially weakened gypsum.

Gypsum resistance to compression is not high. Its average uniaxial compressive strength (UCS) is around $13.73 \mathrm{MPa}$, but it demonstrates considerable variability between 9.41 to $15.99 \mathrm{MPa}$ [14]. While, others found their UCS is medium/moderately strength, varied from 24.1-40.8 and 18-36 MPa generally [3 \& 13].

Clearly, exposure to water is a key control on gypsum dissolution [10]. The chemical composition of this water is important and cause significant variability in rates. As a result, to control this, distilled water has commonly been used in experimental studies on dissolution. The degree of saturation also affects gypsum strength as measured in mechanical tests $[1,7,8,9 \& 16]$, as may the soaking pe$\operatorname{riod}[9 \& 14]$.

\section{[2 Materials and Methods]}

The collection of gypsum in Iraq was limited by security concerns, though some samples could be collected from Bazyan, North of Iraq. Similar gypsum occurs in the highest strata of the Triassic Norian Mercia Mudstone Group (Cropwell Bishop Formation) at Bantycock mine [17]. Both of sites feature thick gypsum rock layer, similar to those beneath the Mosul Dam.

$\mathrm{NX}$ cylinder samples $(54 \mathrm{~mm}$ diameter and $\mathrm{L} / \mathrm{D}=2.5)$ were prepared following common practice $[2,4 \& 6]$. A suitable loading rate of $0.025 \mathrm{MPa} / \mathrm{sec}$ was determined following ASTM and ISRM standards [2 \& 4]. A circumferential extensometer was used in the mid height of cylinders to calculate the radial strain (fig. $2 / \mathrm{C}$ ). Ultrasonic observations were recorded for each sample in air dry state and after each of the immersion periods.

Unloaded gypsum samples were slowly saturated by vacuum, then soaked at atmospheric pressure at 5,10, 15, 30 and 50 weeks. Three samples were used at each time interval for short-term loading tests. Continuous loading (2688 kPa) using a modified oedometer was also applied to samples for 50 weeks. During soaking, the water was changed every 7 days and conductivity measurements taken. A full account of the methodology can be found in Salih (2013)[15]. 


\section{[3 Results]}

\section{[3.1 short-Term Results]}
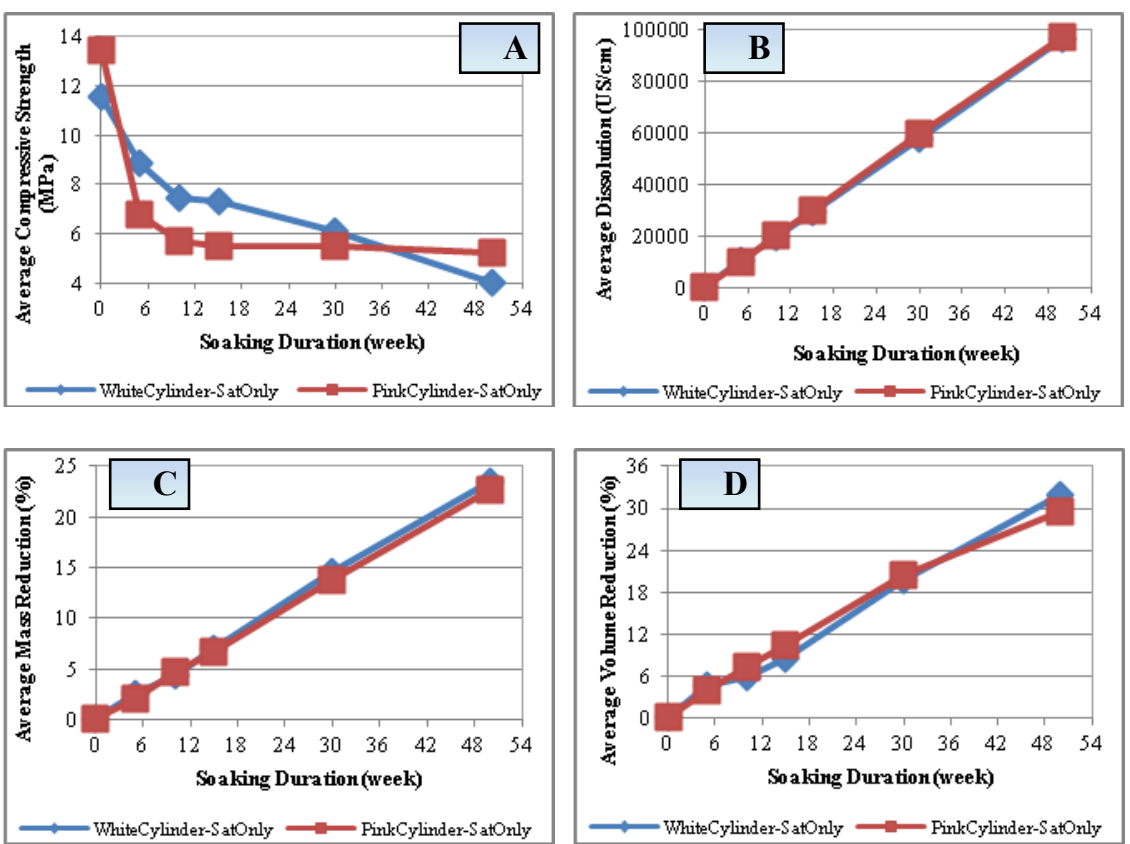

Fig. 1 Comparisons among short term loaded cylinders. A is for compressive strength. $\mathrm{B}$ is for dissolution. $\mathrm{C}$ is for mass reduction and $\mathrm{D}$ is for volume reduction. Each calculated values are the average of three tested cylinders.
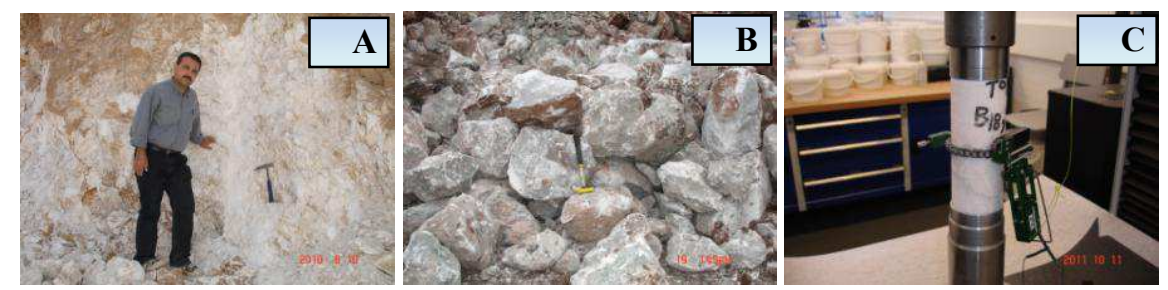

Fig. 2 A. Gypsum outcrop, Bazyan/Iraq. B. Bantycock Mine/UK gypsum blocks. C. The extensometer in the mid-length of a cylinder. 


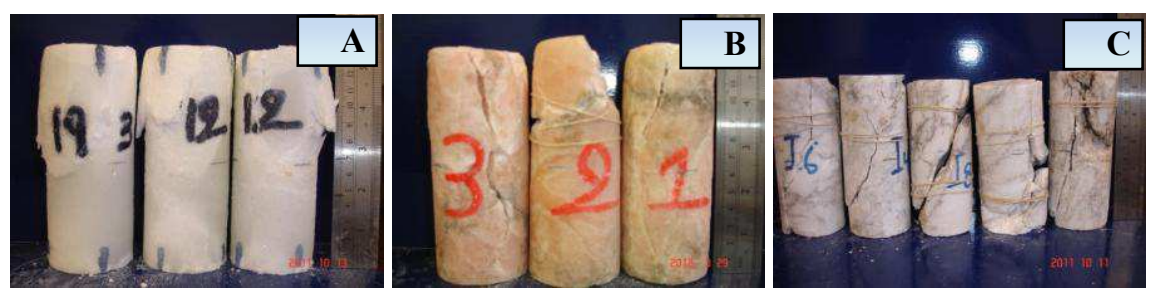

Fig. 3 The failed cylinders after short-term loading: A. the white/Bantycock gypsum. B. the pink/Bantycock gypsum. C. the Iraqi gypsum.
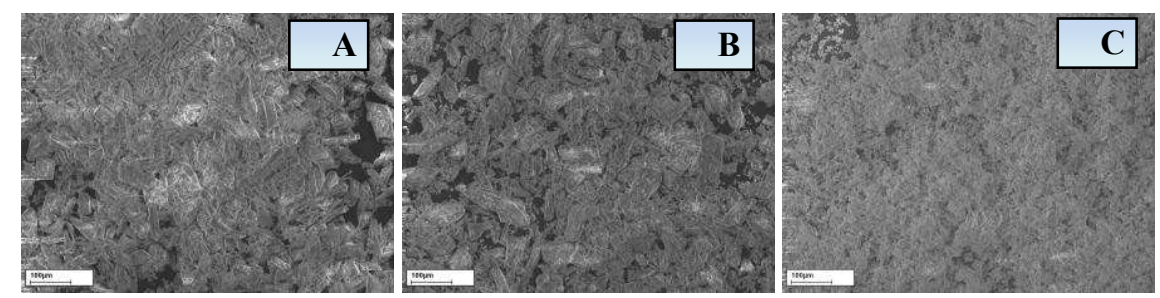

Fig. 4 Variations in gypsum crystal size, visualized using SEM: A. White/Bantycock gypsum. B. Pink/Bantycock gypsum. C. Iraqi gypsum.

Table 1 Description of the UK and Iraqi gypsum particles, the description based on SEM (Scanning Electronic Microscope) photos presents in fig. 4.

\begin{tabular}{|c|c|c|c|c|}
\hline $\begin{array}{c}\text { Gypsum } \\
\text { Sample Type }\end{array}$ & $\begin{array}{l}\text { Particle } \\
\text { Size }\end{array}$ & $\begin{array}{l}\text { Particles } \\
\text { Grada- } \\
\text { tion }\end{array}$ & $\begin{array}{l}\text { Particles } \\
\text { Shape }\end{array}$ & Notes \\
\hline $\begin{array}{l}\text { White/ } \\
\text { Bantycock, } \\
\text { UK } \\
\text { (see fig. } \\
\text { 4/A) }\end{array}$ & $\begin{array}{l}4 \text { to } \\
114 \\
\text { micron }\end{array}$ & $\begin{array}{l}\text { Poorly } \\
\text { graded }\end{array}$ & $\begin{array}{c}\text { Have three } \\
\text { shapes random- } \\
\text { ly: longitudinal, } \\
\text { semi-square and } \\
\text { semi- } \\
\text { circular/elliptical }\end{array}$ & $\begin{array}{c}\text { Very sharp } \\
\text { edges of particles, } \\
\text { mostly medium } \\
\text { size, some large } \\
\text { and small sizes } \\
\text { are found }\end{array}$ \\
\hline $\begin{array}{c}\text { Pink/ } \\
\text { Bantycock, } \\
\text { UK } \\
\text { (see fig. 4/B) }\end{array}$ & $\begin{array}{l}2 \text { to } \\
177 \\
\text { micron }\end{array}$ & $\begin{array}{r}\text { Not very } \\
\text { well graded }\end{array}$ & $\begin{array}{l}\text { Mostly semi- } \\
\text { elliptical and } \\
\text { longitudinal }\end{array}$ & $\begin{array}{l}\text { Middle and } \\
\text { large sizes are } \\
\text { more than fine } \\
\text { size }\end{array}$ \\
\hline $\begin{array}{c}\text { Iraqi } \\
\text { (see fig. } 4 / C \text { ) }\end{array}$ & $\begin{array}{l}1 \text { to } 28 \\
\text { micron }\end{array}$ & $\begin{array}{c}\text { Looks } \\
\text { well graded }\end{array}$ & $\begin{array}{l}\text { Mostly semi- } \\
\text { circular and } \\
\text { semi-elliptical }\end{array}$ & $\begin{array}{c}\text { Mostly fine } \\
\text { particles, some } \\
\text { concentration of } \\
\text { fine particles with } \\
\text { impurities/other } \\
\text { minerals together } \\
\text { make dense look } \\
\text { for some places }\end{array}$ \\
\hline
\end{tabular}


Table 2 Ultrasonic observation of white/Bantycock gypsum cylinders

\begin{tabular}{|l|c|c|c|c|}
\hline $\begin{array}{c}\text { Cylinder } \\
\text { State }\end{array}$ & $\begin{array}{c}\text { Transit } \\
\text { Time (Useos) }\end{array}$ & $\begin{array}{c}\text { Velocity } \\
(\mathrm{m} / \mathrm{sec})\end{array}$ & $\begin{array}{c}\text { Path } \\
\text { Length }(\mathrm{mm})\end{array}$ & $\begin{array}{c}\text { Elastic Modulus } \\
(\mathrm{GPa})\end{array}$ \\
\hline Air-Dry & 27.77 & 18870.67 & 108.67 & 159.7 \\
\hline \multicolumn{5}{|c|}{ Saturated under atmospheric pressure } \\
\hline 5 week & 27.03 & 18821.7 & 108 & 100.2 \\
\hline 10 week & 26.3 & 18821.67 & 104.66 & 82.97 \\
\hline 15 week & 26.17 & 18498.33 & 104.33 & 68.27 \\
\hline 10 week & 19.833 & 15974.33 & 79.33 & 63.47 \\
\hline 15 week & 10.633 & 14588.67 & 42 & 61.2 \\
\hline
\end{tabular}

\section{[3.2 Long-Term Results]}
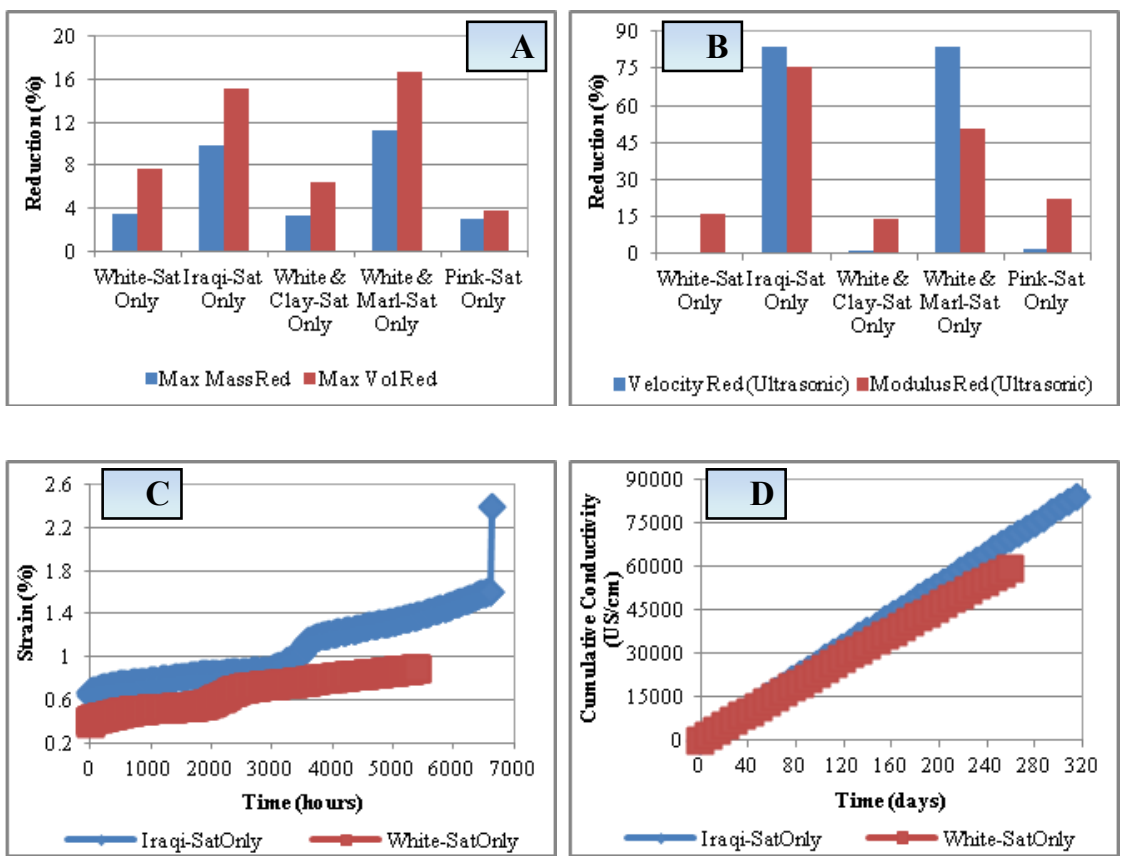

Fig. 5 Comparisons among long-term loaded cylinders. A. Volume and mass reduction after 60 days. B. Ultrasound velocity and modulus reduction after 60 days. C \& D are for one year loaded cylinders, Iraqi cylinder failed after 6800 hours as shown in part $\mathrm{C}$. 


\section{[4 Discussion]}

It is clear that saturation weakens gypsum rock, and this weakness progressively develops over time where there is a flow of water. This is relevant to the context of dams, and other large structures, where groundwater flow is enhanced, and where fresh water is constantly being introduced to the gypsum.

All the samples showed signs of dissolution, manifested as a change in shape over time. This change in shape does not, however, explain all the weakening that took place. There must also be a contribution from changes taking place within the samples.

Several characteristics of the gypsum influence the rate of dissolution weakening. Iraqi samples dissolved at a faster rate that the UK samples. This appears to be due to the size of the gypsum crystals, which were larger in the samples from Bantycock mine.

The larger dissolution values of Iraqi samples under atmospheric pressure than white/Bantycock samples in short-term datasets (fig. 1) were correlated with the effects of gypsum crystal size and shape in characterizing the dissolution process i.e. larger crystals dissolve less quickly than smaller crystals. Slight differences in impurities within the gypsum, as reflected by the different colours of gypsum from Bantycock (white and pink) may also contribute to differences in response e.g. fig. 1/A where the strength of the pink gypsum declines much more quickly than the white gypsum. The shape of internal structures, determined by cracks and fissures, may also be a factor as these allow fresh water to penetrate the gypsum. In addition, many of the cracks contain impurities that have different mechanical and chemical properties to the gypsum. Samples that were soaked without loading showed more evidence of weakening through crack-enhanced dissolution than samples under constant load for 50 weeks. This may be because the high load caused the cracks to close through simple translational movement and through small amounts of creep. It should be noted that the water was under atmospheric pressure during these tests. Under pressure conditions similar to those found beneath large dams such as at Mosul, water may well be able to penetrate thin cracks.

The research has a number of implications for large structures than both load the ground and modify groundwater flow, such as large dams:

- The role of percolating fresh water in enhancing dissolution is confirmed. The significant head difference induced by a dam can be expected to increase the potential for groundwater flow and increase the likelihood of cavity formation. Similar effects could be induced by localized dewatering, or by wetter conditions caused by climate change.

- Importantly, the dissolution does not just generate macro-cavities. There is also alteration of apparently intact gypsum which increases its potential for failure. 
- Sometimes subtle differences in gypsum, such as impurities and crack frequency can have a significant impact on the timing of failure.

\section{[5 Conclusion]}

The research has shown that the evolving behavior of weak soluble rocks such as gypsum can be investigated in the laboratory over extended periods. It highlights that the hazard presented by such rocks is not just simply one of dissolution induced cavities. It is also a progressive weakening of the rock mass itself.

Clearly, the findings suggest that the risk of failure in large dams is a result of a more complex set of processes than may have been expected. This has implications for mitigation solutions. If the problem is perceived as just being caused by cavity formation, then a solution might be to simply fill the cavities with grout on an ad hoc basis. This ignores the weakening of the 'solid' gypsum - and may make the problem worse. Localized injections of grout are likely to deflect and focus groundwater flow on the intact gypsum. This creates a risk of enhanced generation of new cavities, and of forcing more water into the gypsum and so reducing its overall strength.

Other than removing dams such as that at Mosul and elsewhere - an unattractive option given the need for water and power - the only solution is a systematic approach to creating a deep impermeable barrier that will significantly slow, or even stop, the movement of fresh water through the gypsum rock. Such a solution will inevitably be expensive, and challenging to achieve, but the cost must be weighed up against the risk of losing an essential piece of infrastructure.

\section{[6 References]}

1. Ali, S.A. 1979. Creep Properties of Evaporite Rocks with Particular Reference to Gypsum. Ph.D. Thesis, University of Sheffield, UK.

2. ASTM, 2010. Standard Test Method Compressive Strength and Elastic Moduli of Intact Rock Core Specimens under Varying States of Stress and Temperatures. ASTM Standards D7012-10, (Approved 15/01/2010).

3. Bell, F.G., 1981. Geotechnical Properties of Some Evaporitic Rocks. Bulletin 24 of the International Association of Engineering Geology, pp. 137-144.

4. Bieniawski, Z.T., Franklin, J.A., Bernede, M.J., Duffaut, P., Rummel, F., Horibe, T., Broch ,E., Rodrigues, E., Van Heerden, W. L., Vogler, U.W., Hansagi, I., Szlavin, J., Brady, B.T., Deere, D.U., Haweks, I., Milovanovic, D., 1978. Suggested Methods for Determining the Uniaxial 
Compressive Strength and Deformability of Rock Materials. International Journal of Rock Mechanics and Mining Sciences \& Geomechanics Abstracts 16 (2), 135-140. Known by ISRM.

5. Cooper, A.H., 2006. Gypsum Dissolution Geohazards at Ripon, North Yorkshire, UK. Field Trip Guide Ripon, IAEG 2006.

6. Dreybrodt, W., Romanov, D., Gabrovsek, F., 2002. Karstification below Dam Sites: a Model of Increasing Leakage from Reservoirs. Environmental Geology 42, 518-524.

7. Elizzi, M.A.S. 1976. The Time Dependent Behaviour of some Evaporite Rocks. Ph.D. Thesis, University of Sheffield, UK.

8. Ergun, K., Yilmaz, I., 2000. Geotechnical Evaluation of Miocene Gypsum from Sivas-Turkey. Geotechnical and Geological Engineering 18, 79-90.

9. Gao, H., Liang, W., Yang, X., Zhang, G., Yue, G., Zhang, P., 2011. Experimental Study of Mechanical Property of Gypsum Rock Soaked in Hot Saturated Brine. Chinese Journal of Rock Mechanics and Engineering 30 (5), 935-943.

10. Jassim, S. Z., Goff, C. J., 2006. Geology of Iraq. Dolin: Prague and Moravian Museum, Brno.

11. Johnson, K.S., 2005. Subsidence Hazards due to Evaporite Dissolution in the United States. Environ Geol 48, 395-409.

12. Johnson, K.S., 2006. Gypsum-Karst Problems in Constructing Dams in the USA. Environ Geol 53, 945-950.

13. Karacan, E., Yilmaz, I., 1997. Collapse Dolines in Miocene Gypsum: an Example from SW Sivas (Turkey). Environmental Geology 29 (3/4), 263-266.

14. Kenneth, S. J., 2005. Subsidence Hazards Due to evaporite Dissolution in the United States. Environ Geol 48, 395-409.

15. Salih, N.B. 2013. Stability of Dams Constructed on Problematic substrates. Ph.D. Thesis, Brunel University/London, UK.

16. Sonnenfeld, P., 1984. Brines and evaporates. Academic Press, London.

17. Ulker, Worley, N. and Reeves, H. (2007) 'Field Guide, Application of Engineering Geology to Surface Mine Design, British Gypsum, Newark Nottinghamshire'. Field Guide [Online]. Available at: http://nora.nerc.ac.uk/3225/1/Keyworth_Field_Trip.pdf (Accessed: 21 November 2012). 